\title{
ARBUSCULAR MYCORRHIZAL FUNGUS ENHANCES MAIZE (ZEA MAYS L.) GROWTH AND ORGANIC CARBON SEQUESTRATION IN WHEAT (TRITICUM AESTIVUM L.) STRAW-AMENDED SOILS
}

\author{
HU, J.L. ${ }^{1,2,3}-$ CUI, X.C. ${ }^{1,2}-$ LIN, X.G. ${ }^{1,2} *$ - DAI, J. ${ }^{1,2}-$ CHEN, R.R. ${ }^{1,2}-$ WANG, J.H. ${ }^{1,2}-$ \\ WONG, M.H. ${ }^{2,3}$

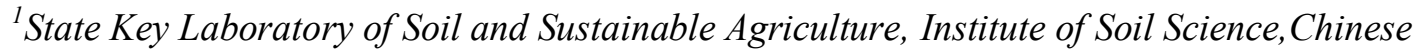 \\ Academy of Sciences \\ East Beijing Road 71, Nanjing 210008, P. R. China \\ (phone: +86-25-86881589; fax: +86-25-86881000) \\ ${ }^{2}$ Joint Open Laboratory of Soil and the Environment, Hong Kong Baptist University \& Institute of \\ Soil Science, Chinese Academy of Sciences \\ East Beijing Road 71, Nanjing 210008, P. R. China \\ ${ }^{3}$ Croucher Institute for Environmental Sciences, Department of Biology, Hong Kong Baptist \\ University \\ Kowloon Tong, Hong Kong SAR, P. R. China \\ *Corresponding author \\ e-mail:jlhu@issas.ac.cn;xglin@issas.ac.cn \\ (Received $18^{\text {th }}$ Nov 2011; accepted $22^{\text {nd }}$ July 2014)
}

\begin{abstract}
A pot experiment was conducted to investigate the effects of wheat (Triticum aestivum L.) straws and arbuscular mycorrhizal (AM) fungi on maize (Zea mays L.) growth and organic carbon (C) sequestration in a sterilized sandy loam soil. The experiment included three treatments: control, amendment with wheat straws (S), and amendment with wheat straws plus inoculation with AM fungus Glomus caledonium $(\mathrm{S}+\mathrm{M})$. Compared with the control, the amendment of wheat straws significantly $(P<0.05)$ increased soil alkaline phosphatase (ALP) activity in maize seedling period (30 d) and plant phosphorus (P)-uptake and shoot biomass at harvest time (110 d), and also tended to increase soil organic $\mathrm{C}$ content as well as produced low but demiurgic crop yield at harvest time. In wheat straw-amended soils, $G$. caledonium inoculation significantly $(P<0.05)$ decreased soil $\mathrm{pH}$ and significantly $(P<0.05)$ increased plant P-uptake as well as soil ALP activity in seedling period, and tended to increase shoot biomass and grain yield in seedling and harvest periods, respectively. Furthermore, G. caledonium inoculation tended to increase soil organic $\mathrm{C}$ content at harvest time, which was significantly $(P<0.05)$ higher than that of the control, suggesting potential application of AM fungi in facilitating crop production and $\mathrm{C}$ sequestration in straw-returned fields.
\end{abstract}

Keywords: alkaline phosphatase, Glomus caledonium, P-uptake, rhizosphere acidification, straw return 


\section{Introduction}

Soil organic carbon (C), an important component of terrestrial ecosystems, is a crucial regulator of $\mathrm{C}$ fluxes between the biosphere and the atomosphere (Zhu and Mille, 2003). Soil $C$ storage depends on the balance between $C$ input and output. Optimizing agricultural managements can increase soil $\mathrm{C}$ by increasing $\mathrm{C}$ input and/or decreasing $\mathrm{C}$ output (Lu et al., 2009). Organic amendments are used primarily to increase nutrient availability to plants, and are essential for improving soil organic $\mathrm{C}$ content as well (Zhong et al., 2010). For instance, straw, the dry stalks of cereal plants, is an agricultural by-product after the grain and chaff have been removed. Since recycling of nutrients is the key to nutrient management in sustainable agricultural system, the management of straw in the field as crop residue for returning the organic matter to the soils is significant in agricultural production (Tuyen and Tan, 2001). Although straw has value from both the nutrients removed and the organic matter addition it will return to the soil, the value of the organic matter that straw returns to the soil is much more difficult to calculate, and it is the activity of microbe and enzyme that regulates $\mathrm{C}$ accumulation via mineralization and immobilization of plant derived residues in the soil.

Phosphorus $(\mathrm{P})$ is one of the major essential macronutrients limiting plant growth owing to its low bioavailability in soils (Feng et al., 2004), and improving plant acquisition of $\mathrm{P}$ from soil is an obvious alternative to the management of those low $\mathrm{P}$ soils (Zhu et al., 2003). It is commonly known that arbuscular mycorrhizae (AMs) provide a direct link between soil and roots: AM fungi help plants to capture water and nutrients (notably P) from the soil, and in return, the plant provides the fungus with relatively constant and direct access to carbohydrate (Smith and Read, 2008), which are translocated from their source to root tissue and on to fungal partners. It is also generally accepted that AM fungi receive all their carbohydrate from host plant and that the association could create a sink demand for carbohydrate, which could result in a 4-20\% drain of C from the host plant and could indirectly influence C storage in soils (Graham, 2000).

Although straw return can increase $\mathrm{C}$ input to soil from crop residues, uncertainties still remain about the impacts of AMs on crop production and soil organic $\mathrm{C}$ sequestration in straw-returned soils. Then, the objectives of this study were to investigate the effects of AMs on maize (Zea mays L.) growth and organic C sequestration in a wheat (Triticum aestivum L.) straws-amended soil, and find out the main factors that influence these parameters.

\section{Materials and methods}

\section{Soil and mycorrhizal inoculum preparation}

A subsurface soil sample was collected from an arable agricultural land at Fengqiu County $\left(35^{\circ} 00^{\prime} \mathrm{N}, 114^{\circ} 24^{\prime} \mathrm{E}\right)$, Henan Province, China. The air-dried soil sample was ground with a wooden pestle, homogenized by sieving through a $5 \mathrm{~mm}$ sieve, autoclaved $\left(121^{\circ} \mathrm{C}\right.$ for $1 \mathrm{~h}$ on three successive days), and stored for the pot experiment. 
The soil is derived from alluvial sediments of the Yellow River and classified as aquic inceptisol with the following properties: soil $\mathrm{pH}$ (soil: water ratio of 1: 2.5) 8.6, $3.66 \mathrm{~g}$ $\mathrm{kg}^{-1}$ organic $\mathrm{C}, 0.35 \mathrm{~g} \mathrm{~kg}^{-1}$ total $\mathrm{N}, 0.55 \mathrm{~g} \mathrm{~kg}^{-1}$ total $\mathrm{P}$, and $22 \mathrm{~g} \mathrm{~kg}^{-1}$ total K. Glomus caledonium (Nicol. \& Gerd.) Trappe \& Gerdemann 90036 was isolated from a fluvo-aquic soil in Hennan Province, China (Liao et al., 2003), and deposited at the Institute of Soil Science, Chinese Academy of Sciences, Nanjing, China. The AM inocula were propagated on white clover (Trifolium repens L.) grown in an autoclaved $\left(121^{\circ} \mathrm{C}\right.$ for $1 \mathrm{~h}$ on 3 successive days) substrate for two successive propagation cycles (4 months each). The inocula were a mixture of rhizospheric soil containing spores, hyphae, and mycorrhizal root fragments, and were air-dried and sieved $(2 \mathrm{~mm})$. At the same time, the non-mycorrhizal inoculum was also prepared with the same sterilized substratum on which white clover was cultivated under the same conditions.

\section{Pot experiment}

Three treatments were established in the pot experiment: control, amendment with wheat straw (S), and amendment with wheat straw plus inoculation with G. caledonium $(\mathrm{S}+\mathrm{M})$. Each square polyvinyl chloride $(\mathrm{PVC})$ pot $(30 \times 30 \times 30 \mathrm{~cm})$ contained $7.5 \mathrm{~kg}$ of soil, which was mixed with $375 \mathrm{~g}$ of mycorrhizal/nonmycorrhizal inoculum, and each straw amendment treatment was also mixed with $37.5 \mathrm{~g}$ of wheat straw $(<1 \mathrm{~cm})$. Six maize seeds were sown into each box, and three seedling per box were left after emergence. Plants were grown in a sunlit glasshouse with $30 / 22^{\circ} \mathrm{C}$ day/night temperature, $40-60 \%$ relative humidity and $60-70 \%$ water-holding capacity. Pots were randomly arranged with four replicates per treatment. Two maize seedlings per pot was harvested after growing for 30 days, and the other one was harvested after growing for 110 days. At each sampling time, soil samples were also collected.

\section{Mycorrhizal colonization, plant and soil analysis}

Wheat plants were divided into roots, shoots, and grains if possible. Fresh roots were used for mycorrhizal colonization assessment by the grid-line intersect method (Giovannetti and Mosse, 1980) after rinsing with tap water, clearing with $10 \% \mathrm{KOH}$ and staining with acid fuchsin (Phillips and Hayman, 1970). Shoots and grains were weighed after oven drying at $70{ }^{\circ} \mathrm{C}$ for $48 \mathrm{~h}$, and subsamples of dried and ground shoots and grains were taken for immediate nitric-perchloric acid digestion in $\mathrm{HNO}_{3}(70 \%)$ : $\mathrm{HClO}_{4}(70 \%)$ mixture (6:1 v/v) (Zhu et al., 2003), followed by molybdenum-ascorbic acid spectrophotometry (Hanson, 1950), to measure tissue P concentration. To this end, the individual P-uptake by maize plant (shoot plus grain) was calculated. Soil samples were air-dried and homogenized by sieving through a $2 \mathrm{~mm}$ mesh sieve. Soil $\mathrm{pH}$ was determined with a glass electrode using a soil-to-water ratio of 1:2.5. Soil alkaline phosphatase activity was determined by incubation at $37{ }^{\circ} \mathrm{C}$ with borate buffer $(\mathrm{pH} 9)$ according to the method of Tabatabai (1982), and is given in units of $\mathrm{mg} p$-nitrophenol produced $\mathrm{g}^{-1}$ soil $24 \mathrm{~h}^{-1}$. Then, the enzyme activity was expressed on an oven-dried soil 
weight basis by correcting for water content in the soil $\left(105^{\circ} \mathrm{C}, 24 \mathrm{~h}\right)$. To this end, soil organic $\mathrm{C}$ content was determined by dichromate oxidation (Mebius, 1960).

\section{Statistical analysis}

The means and standard deviations of four replicates were computed. An analysis of variance was carried out using the one-way procedure with SPSS software while the comparison of mean effects was based on least significant difference (LSD) multiple-comparison tests $(P<0.05)$.

\section{Results}

\section{Mycorrhizal colonization, shoot biomass, grain yield, and P uptake of maize plant}

Mycorrhization in maize roots was shown in the G. caledonium-inoculated treatment (Table 1), and the colonization rates were $31.7 \pm 3.1 \%$ and $50.3 \pm 2.9 \%$ in seedling $(30 \mathrm{~d})$ and harvest $(110 \mathrm{~d})$ periods, respectively. The amendment of wheat straw significantly $(P<0.05)$ increased maize shoot biomass and P-uptake at harvest time but not in seedling period, and produced low but demiurgic crop yield, which approached zero in the control soils. In wheat straw-amended soils, G. caledonium inoculation significantly $(P<0.05)$ increased maize $\mathrm{P}$-uptake and tended to increase maize shoot biomass in seedling period as well, but had no significant effects on them at harvest time, except for a trend towards higher grain yield.

Table 1. Mycorrhizal colonization, shoot biomass, grain yield, and P-uptake of maize plant under different treatments.

\begin{tabular}{|c|c|c|c|c|c|}
\hline $\begin{array}{l}\text { Sampling } \\
\text { time }\end{array}$ & Treatment & $\begin{array}{l}\text { Mycorrhizal } \\
\text { colonization } \\
(\%)\end{array}$ & $\begin{array}{l}\text { Individual } \\
\text { shoot biomass } \\
\text { (g) }\end{array}$ & $\begin{array}{l}\text { Individual } \\
\text { grain yield } \\
\text { (g) }\end{array}$ & $\begin{array}{l}\text { Individual } \\
\text { P-uptake } \\
(\mathrm{mg})\end{array}$ \\
\hline \multirow[t]{3}{*}{$30 \mathrm{~d}$} & Control & - & $0.56(0.11) b$ & - & $0.39(0.24) b$ \\
\hline & $\mathrm{S}$ & - & $0.64(0.14) \mathrm{ab}$ & - & $0.59(0.09) \mathrm{b}$ \\
\hline & $\mathrm{S}+\mathrm{M}$ & $31.7(3.1)$ & $0.84(0.10) \mathrm{a}$ & - & $1.05(0.20) \mathrm{a}$ \\
\hline \multirow[t]{3}{*}{$110 \mathrm{~d}$} & Control & - & $5.10(0.40) b$ & - & $3.09(0.36) \mathrm{b}$ \\
\hline & S & - & $8.28(1.38) \mathrm{a}$ & $0.07(0.12)$ & $12.66(1.22) \mathrm{a}$ \\
\hline & $\mathrm{S}+\mathrm{M}$ & $50.3(2.9)$ & $8.35(2.55) \mathrm{a}$ & $2.28(2.44)$ & $11.93(1.21) \mathrm{a}$ \\
\hline
\end{tabular}

Control, without inoculation/amendment; $\mathrm{S}$, amendment with wheat straw; $\mathrm{S}+\mathrm{M}$, amendment with wheat straw plus inoculation with AM fungi. Standard deviations are given in parentheses. Values within the same column and the same cultivation time not followed by the same letter differ significantly $(P<0.05)$. 


\section{Soil pH, alkaline phosphatase activity, and organic $C$ content}

The amendment of wheat straw significantly $(P<0.05)$ increased soil ALP $($ Fig. $1 b)$ activity in maize seedling period, but had no significant effects on soil pH (Fig. 1a) and organic $\mathrm{C}$ content (Fig. 1c) both in maize seedling and harvest periods, except for a trend towards higher organic $\mathrm{C}$ content at maize harvest time. In wheat straw-amended soils, G. caledonium inoculation significantly $(P<0.05)$ decreased soil $\mathrm{pH}$ and significantly $(P<0.05)$ increased soil ALP activity in seedling period, and thereby tended to increase soil organic $\mathrm{C}$ content at maize harvest time, which was significantly $(P<0.05)$ higher than that of the control.
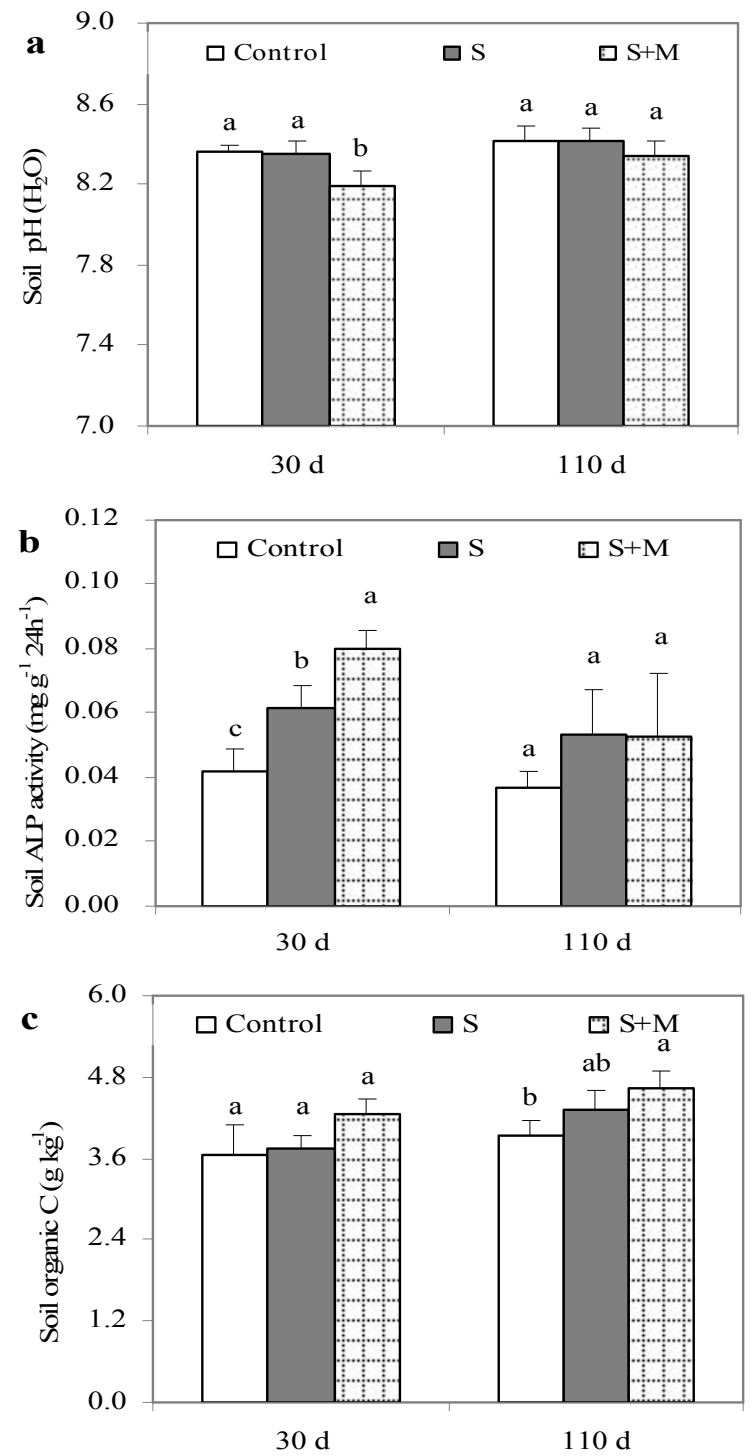

Figure 1. Soil pH (a), alkaline phosphatase activity (b), and organic C content (c) under different treatments. Control, without inoculation/amendment; $S$, amendment with wheat straw; $S+M$, amendment with wheat straw plus inoculation with AM fungi. Vertical $T$ bars indicate standard deviations. Bars within the same cultivation time not topped by the same letter indicate a significant difference in values $(P<0.05)$. 


\section{Discussion}

Organic amendments act as a source of $\mathrm{C}$ and other nutrients, which may improve soil organic $C$ and favor plant growth as well (Albiach et al., 2000), owing to the enhanced plant nutrition. However, mechanisms causing increased grain yield upon AM fungal inoculation in straw-amended soils seem to be due to the rhizosphere acidification and enhanced ALP activity in the seedling period. On the one hand, plant roots alter rhizosphere soil $\mathrm{pH}$ by production or consumption of $\mathrm{H}^{+}$or by exudation of organic acids, and thereby induce changes in nutrient availability ( $\mathrm{Li}$ et al., 1991), and such an effect is possibly enhanced by AM fungal inoculation (Bago et al., 1996). On the other hand, soil ALP activity is also involved in the mycorrhization effect on plant nutrition, since AM propagules themselves synthesize enzymes, such as ALP within the P-accumulating vacuoles of AM hyphae (Dong and Zhao, 2004), and mycorrhizal roots may release more root exudates containing enzymes than non-mycorrhizal roots because of the larger root system and/or improved nutrition (Wang et al., 2006). It is noteworthy that crops seedlings growing in straw-amended soils were still P limited in this study, and the significant increase of plant P-uptake in the seedling period upon AM fungal inoculation played a vital role in deuteric grain filling.

Straw amendment raised grain yield and plant biomass, which would also increase biomass input into soil from crop roots ( $\mathrm{Lu}$ et al., 2009). However, in addition to facilitating plant uptake of mineral nutrients, AM fungi can also impact soil $\mathrm{C}$ dynamics directly by contributing to soil C inputs (Jakobsen and Rosendahl, 1990), and indirectly by modifying the decomposition of organic materials (Tu et al., 2006). Although they are thought to be unable to decompose organic materials directly due to a lack of saprotrophic capacity (Read and Perez-Moreno, 2003), AM fungi may alter rhizosphere soil directly or indirectly through changes in root exudation patterns or fungal exudates (Linderman, 1992), and still be involved in decomposition processes. For example, AM fungi have been found to proliferate in decomposing organic residues (St John et al., 1983), and therefore, may enhance wheat straw decomposition by stimulating some enzyme activities. Consequently, the combined application of wheat straw and AM fungi revealed the strongest influences on soil organic $\mathrm{C}$ content, which may be explained by the multitude of factors that may act in different ways, such as direct $\mathrm{C}$ sources and crop root exudates. Although the results indicated the potential application of AM fungi in facilitating $\mathrm{C}$ sequestration in straw-returned fields, the applying strategy still needs an in-depth study.

In summary, wheat straw increased maize shoot biomass and P-uptake as well as soil ALP activity, and tended to increase soil organic $\mathrm{C}$ content as well as produced low but demiurgic crop yield at harvest time. AM fungal inoculation greatly increased maize grain yield and soil organic $\mathrm{C}$ content in straw-amended soils, and seemed to be due to enhanced rhizosphere acidification and increased nutrients (notably P) uptake in the seedling period. The results indicated potential application of AM fungi in facilitating crop growth and $\mathrm{C}$ sequestration in straw-returned fields. 
Acknowledgements. This work was supported by the National Natural Science Foundation (No.40801090), the National Basic Research Program (2011CB100505), and the Special Fund of Industrial (Agriculture) Research for Public Welfare (200903001) of China.

\section{REFERENCES}

[1] Albiach R., Canet R., Pomares F., Ingelmo F. (2000): Microbial biomass content and enzymatic activities after the application of organic amendments to a horticultural soil. Bioresource Technology 75: 43-48.

[2] Bago B., Vierheilig H., Piché Y., Azcon-Aguilar C. (1996): Nitrate depletion and pH changes induced by the extraradical mycelium of the arbuscular mycorrhizal fungus Glomus intraradices grown in monoxenic culture. - New Phytologist 133: 273-280.

[3] de Datta S.K. (1981): Principles and Practices of Rice Production. John Wiley and Sons, New York.

[4] Dong C., Zhao B. (2004): Arbuscular mycorrhizal formation of crucifer leaf mustard induced by flavonoids apigenin and daidzein. - Chinese Science Bulletin 49: 1254-1261.

[5] Feng K., Lu H.M., Sheng H.J., Wang X.L., Mao J. (2004): Effect of organic ligands on biological availability of inorganic phosphorus in soils. - Pedosphere 14: 85-92.

[6] Giovannetti M., Mosse B. (1980): An evaluation of techniques for measuring vesiculararbuscular mycorrhizal infection in roots. - New Phytologist 84: 489-500.

[7] Graham J.H. (2000): Assessing the cost of arbuscular mycorrhizal symbiosis in agroecosystems. - In: Podila G.K., Douds D.D. (eds.) Current Advances in Mycorrhizal Research, The American Phytopathological Society, St. Paul, MN.

[8] Hanson W.C. (1950): The photometric determination of phosphorus in fertilisers using the phosphovanado-molybdate complex. - Journal of the Science of Food and Agriculture 1: 172-173.

[9] Hu J., Lin X., Wang J., Cui X., Dai J., Chu H., Zhang J. (2010): Arbuscular mycorrhizal fungus enhances P-acquisition of wheat (Triticum aestivum L.) in a sandy loam soil with long-term inorganic fertilization regime. - Applied Microbiology and Biotechnology 88: 781-787.

[10] Jakobsen I., Rosendahl L. (1990): Carbon flow into soil and external hyphae from roots of mycorrhizal cucumber plants. - New Phytologist 115: 77-83.

[11] Li X.L., George E., Marschner H. (1991): Phosphorus depletion and pH decrease at the root-soil and hyphae-soil interfaces of VA mycorrhizal white clover fertilized with ammonium. - New Phytologist 119: 397-404.

[12] Liao J.P., Lin X.G., Cao Z.H., Shi Y.Q., Wong M.H. (2003): Interactions between arbuscular mycorrhizae and heavy metals under sand culture experiment. - Chemosphere 50: 847-853.

[13] Linderman R.G. (1992): Vesicular-arbuscular mycorrhizae and soil microbiota interactions. - In: Bethlenfalvay G.J., Linderman R.G. (eds.) Mycorrhizae in Sustainable Agriculture, American Society of Agronomy, Madison, WI.

[14] Lu F., Wang X., Han B., Ouyang Z., Duan X., Zheng H., Miao H. (2009): Soil carbon 
sequestrations by nitrogen fertilizer application, straw return and no-tillage in China's cropland. Global Change Biology 15: 281-305.

[15] Mebius L.J. (1960): A rapid method for determination of organic carbon in soil. Analytica Chimica Acta 22: 120-124.

[16] Phillips J.M., Hayman D.S. (1970): Improved procedures for clearing roots and staining parasitic and vesicular-arbuscular mycorrhizal fungi for rapid assessment of infection. Transactions of the British Mycological Society 55: 158-161.

[17] Read DJ, Perez-Moreno J (2003) Mycorrhizas and nutrient cycling in ecosystems-a journey towards relevance? - New Phytologist 157: 475-492.

[18] Smith S.E., Read D.J. (2008): Mycorrhizal Symbiosis, 3rd edn. Academic Press, London, UK.

[19] St John T.V., Coleman D.C., Reid C.P.P. (1983): Association of vesicular-arbuscular mycorrhizal hyphae with soil organic particles. - Ecology 64: 957-959.

[20] Tabatabai M.A. (1982): Soil enzymes. - In: Page A.L., Miller R.H., Keeney D.R. (eds.) Methods of Soil Analyses, Part 2, Chemical and Microbiological Properties, 2nd edn, American Society of Agronomy, Madison, WI.

[21] Tu C., Booker F.L., Watson D.M., Chen X., Rufty T.W., Shi W., Hu S. (2006): Mycorrhizal mediation of plant $\mathrm{N}$ acquisition and residue decomposition: Impact of mineral N inputs. - Global Change Biology 12: 793-803.

[22] Tuyen T.Q., Tan P.S. (2001): Effects of straw management, tillage practices on soil fertility and grain yield of rice. - Omonrice 9: 74-78.

[23] Wang F.Y., Lin X.G., Yin R., Wu L.H. (2006): Effects of arbuscular mycorrhizal inoculation on the growth of Elsholtzia splendens and Zea mays and the activities of phosphatase and urease in a multi-metal-contaminated soil under unsterilized conditions. - Applied Soil Ecology 31: 110-119.

[24] Zhong W., Gu T., Wang W., Zhang B., Lin X., Huang Q., Shen W. (2010): The effects of mineral fertilizer and organic manure on soil microbial community and diversity. - Plant and Soil 326: 511-522.

[25] Zhu Y.G., Miller R.M. (2003): Carbon cycling by arbuscular mycorrhizal fungi in soil-plant systems. - Trends in Plant Science 8: 407-409.

[26] Zhu Y.G., Smith F.A., Smith S.E. (2003): Phosphorus efficiencies and responses of barley (Hordeum vulgare L.) to arbuscular mycorrhizal fungi grown in highly calcareous soil. Mycorrhiza 13: 93-100. 